\title{
Incidence of Humeral Head of Biceps Brachii Muscle. Anatomical Insight
}

\author{
Incidencia de la Cabeza Humeral del Músculo Bíceps Braquial - Visión Anatómica
}

Isurani Ilayperuma; Ganananda Nanayakkara \& Nadeeka Palahepitiya

ILAYPERUMA, I.; NANAYAKKARA, G. \& PALAHEPITIYA, N. Incidence of humeral head of biceps brachii muscle - Anatomical insight. Int. J. Morphol., 29(1):221-225, 2011.

SUMMARY: Biceps brachii is stated as one of the muscles that shows most frequent anatomical variations. Its most commonly reported anomaly is the presence of an accessory fascicle arising from the humerus which is termed as the humeral head of biceps brachii. Evidence shows a clear racial trend in the incidence of the humeral head of biceps brachii. Therefore, detailed knowledge of this variation in different populations is important for surgical interventions of the arm, nerve compression syndromes and in unexplained pain syndromes in the arm or shoulder region. The goal of this study was to elucidate the incidence and morphological features of this muscle in an adult Sri Lankan population. Upper extremities of the total of one hundred thirty five cadavers were dissected and studied for the presence of accessory heads of the biceps brachii muscle. The proximal and distal attachments of the humeral heads as well as their cranio-caudal, antero-posterior and medio-lateral dimensions were recorded. The incidence of humeral head of biceps brachii was found to be $3.7 \%$. In all cases, it was found unilaterally and only in male subjects. The humeral head originated from the antero-medial aspect of the humeral shaft and descended and merged with the other two heads to form a common tendon. The results of the present study further highlight the racial variations in the incidence of humeral head of biceps brachii among Sri Lankans. Knowledge of the occurrence of humeral head of biceps brachii may facilitate preoperative diagnosis as well as the surgical procedures of the upper limb thus avoiding iatrogenic injuries.

KEY WORDS: Humeral head of biceps brachii; Anatomical variation; Sri Lankan.

\section{INTRODUCTION}

The biceps brachii, a muscle of the anterior compartment of the upper limb, has been characteristically described as having a long head originated from the supraglenoid tubercle and glenoid labrum and a short head from the coracoid process of the scapula. Distally these two heads unite to form a common tendon that inserts into the posterior rough part of the radial tuberosity and bicipital aponeurosis which merges with the deep fascia of the forearm (Williams et al., 2000). This mode of insertion makes it an efficient and important supinator of the forearm. It is the only flexor of the arm that crosses the shoulder as well as the elbow joint thereby acting on both joints. It is innervated by the musculocutaneous nerve and vascularized by brachial and anterior circumflex humeral arteries and brachial vein (Williams et al.).
Biceps brachii has been stated as one of the muscles that shows frequent anatomical variations (Testut \& Latarjet, 1981; Asvat et al., 1993; Nakatani et al., 1998; Nayak et al., 2008). Some of its reported anomalies have been manifested as accessory fascicles that originate from the coracoid process, tendon of pectoralis major, articular capsule and head of the humerus or from humerus itself (Sargon et al., 1996). Among those variations, the presence of an accessory fascicle arising from the shaft of the humerus, which is known as the humeral head of biceps brachii, is known to be the most common anomaly (Khaledpour; 1985; Asvat et al.; Kopuz et al., 1999). Multiple accessory heads of four to seven have also been reported to a lesser extent (Asvat et al.; Nakatani et al.; Williams et al.; Nayak et al.).

Department of Anatomy, Faculty of Medicine, University of Ruhuna, Sri Lanka. 
A large body of evidence suggests a wide range of racial variations in the occurrence of humeral head of biceps brachii muscle. It was shown to have an incidence of $7.1 \%$ in Indians, $8 \%$ in Chinese, $10 \%$ in European whites, $12 \%$ in African Blacks, $15 \%$ in Turkish, $18 \%$ in Japanese, $21.5 \%$ in South African Blacks and $8.3 \%$ in South African Whites, and $37.5 \%$ in Colombians (Rai et al., 2007; Bergman et al., 1988; Torre et al., 1994; Kosugi et al.,1992; Asvat et al.; Kumar et al., 2008; Kopuz et al., 1999; Tountas \& Bergman, 1993; Rincon et al., 2002; Sweiter \& Carmichael, 1980).

From a clinical standpoint of view, muscle anomalies are difficult to differentiate from soft tissue tumors (Nayak et al.). High median nerve compression around the elbow joint has been described as resulting from a number of clinical and anatomical entities. The existence of an anomalous muscle in and around the elbow region may cause high median nerve palsy and compression of the brachial artery (Nayak et al.). Further, knowledge of the incidence of humeral head of biceps brachii will facilitate preoperative diagnosis as well as the surgical procedures of the upper limb (Rai et al.; Nayak et al.).

Despite its significance little is known regarding the occurrence of the third head of biceps brachii in Sri Lankans, inhabitants of the South Asian country. Hence, this study was carried out to elucidate the incidence and morphological features of the third head of biceps brachii muscle in an adult Sri Lankan population.

\section{MATERIAL AND METHOD}

This study was carried out on a total of one hundred and thirty five apparently healthy human cadavers ( 81 males and 54 females) during routine gross anatomy dissections in the Department of Anatomy, Faculty of Medicine, University of Ruhuna, Galle, Sri Lanka. The cadavers were preserved in $10 \%$ formalin. The age group of the cadavers varied between 48-67 years.

A longitudinal incision was made on the anterior aspect of the arm extending from the level of acromian process to a point $2.5 \mathrm{~cm}$ below the elbow joint. Then horizontal incisions were made bilaterally on both proximal and distal ends of the longitudinal incision. The skin, subcutaneous fat and fascia of the arms were dissected carefully to expose the full length of the biceps brachii muscle from its proximal to distal attachment.
The presence of accessory heads, their origins and insertions were recorded. The cranio-caudal, anteroposterior and medio-lateral dimensions of the humeral heads were recorded using a digital sliding caliper (Mitutoyo, Japan) capable of measuring to the nearest $0.01 \mathrm{~mm}$.

All the measurements were repeated thrice and the mean was taken for further analysis. Furthermore, the measurements were recorded by the same person to minimize the errors in methodology. Results were expressed as mean $\pm \mathrm{SD}$.

\section{RESULTS}

Out of 270 upper limbs of 135 cadavers humeral heads of the biceps brachii were present in 5 upper limbs of the study subjects. Supernumerary heads of biceps brachii muscle were absent bilaterally in 130 cadavers and unilaterally on 5 cadavers. The incidence of humeral head of biceps brachii in the present study was found to be $3.7 \%$. In all cases, when present, it was found unilaterally and only in male subjects.

In all the study subjects, the humeral head of biceps brachii originated from the antero-medial aspect of the lower third of the humeral shaft between the origin of brachialis and insertion of coracobrchialis muscles. It descended and merged with the other two heads to form a common tendon which inserted into the radial tuberosity and bicipital aponeurosis. The accessory head was lying deep and fused with the common muscle belly of the biceps brachii at the distal third of the arm. The long and short heads of biceps brachii muscles had their normal attachments and relations (Fig. 1. a, b and c).

The dimensions of the muscle body of the humeral head were $12.46 \pm 42 \mathrm{~cm}$ cranio-caudally, $2.45 \pm 0.02$ $\mathrm{cm}$ medio-laterally and $0.52 \pm 0.04 \mathrm{~cm}$ anteroposteriorly. The length of the biceps brachii common tendon was $7.02 \pm 0.34 \mathrm{~cm}$. The humeral head was related anteriorly to the long and short heads of biceps brachii muscle, posteriorly to the brachialis and shaft of the humerus, laterally to the long head of biceps brachii and medially to the median nerve and brachial artery. The third head received its innervation from the musculocutaneous nerve, as do the other two heads of biceps brachii. Short filaments of the musculcutaneous nerve entered the muscle from its superior and anterior aspect. The vascularization of the accessory head was from the brachial artery and vein. 

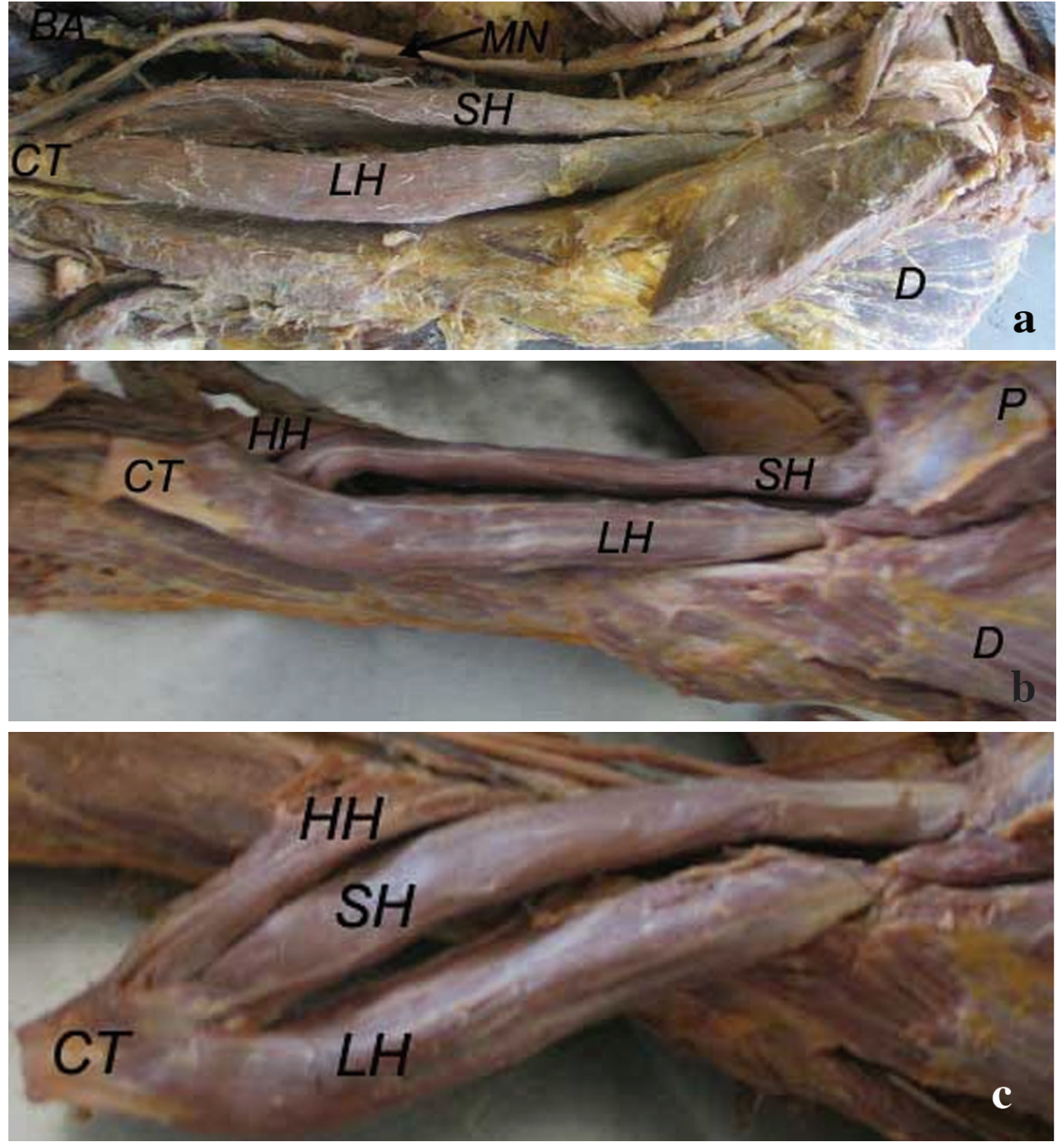

Fig. 1. (a) biceps brachii with two heads; (b) biceps brachii with three heads; (c) same as (b) giving a more clear view of the humeral head. LH - long head of biceps brachii; $\mathrm{SH}$ - short head of biceps brachii; $\mathrm{HH}$ - humeral head of biceps brachii; CT biceps brachii common tendon; MN - median nerve; BA brachial artery; Ddeltoid; $\mathrm{P}$ pectoralis muscle.

\section{DISCUSSION}

The present study documents the incidence and morphological characteristics of humeral heads of biceps brachii in an adult Sri Lankan population. The standard Anatomy text states the incidence of this variation as $10 \%$ (Williams et al.). Although this is in accord with some European populations (Bergman et al.), it ignores a large body of evidence with reference to other populations (Sweiter \& Carmichael; Kosugi et al., 1992; Asvat et al.; Tountas \& Bergman; Torre et al.; Kopuz et al.; Rincon et al.; Rai et al.; Kumar et al.). Furthermore, racial variation of the incidence of the third head of biceps brachii has been clearly demonstrated by comparative studies between Brazilian whites and black subjects (Santo Neto et al., 1998). The incidence third head of biceps brachii in blacks was found to be significantly lower than in whites (Santo Neto et al.). However, it is not clear whether these variations represent a functional adaptation of the reference populations. The variations of the incidence of the third head of biceps brachii were attributed to evolutionary or racial trends (Kopuz et al.). The present study shows the incidence of $3.7 \%$ among Sri Lankan population, a result that further highlights the racial differences in the incidence of third head of biceps brachii observed among different populations. 
It was also interesting to note the gender differences of the occurrence of accessory heads of this muscle. Gender comparison of the incidence implies that third head of the biceps brachii is a predominantly male condition (Bergman et al.; Asvat et al.). The results of the present study are in agreement with the above statement.

Embryologically it has been stated that the third head of biceps brachii arises from the brachialis muscle and in such instances its distal insertion has been translocated from ulna to the radius (Testut \& Latarjet, 1981). The innervation and vascularization of the third head of biceps brachii were from musculocutaneous nerve and brachial artery in the current study as well as those observed in previous studies. This agrees with the normal embryologic development of the related dermatomes and myotomes.

It is presumed that the development of the biceps brachii muscle is likely to influence the course and the branching pattern of musculocutaneous nerve (Warner et al.; Kumar et al.). This may have clinical implication as the musculocutaneous nerve is subjected to compression by the bulky third head. Therefore, knowledge on such variations will be important during surgical manipulations of the arm as well as in diagnosing the nerve impairments. Furthermore, it has been mentioned that any variant nerve with an abnormal origin, course and distribution is prone to accidental injuries and impairments (Roberts, 1992). This is further proved by the fact that supernumery heads of the biceps brachii muscle have been reported to compress the surrounding neurovascular structures leading to erroneous interpretations during surgical procedures (Warner et al.).

The biceps brachii is known for its powerful elbow flexion and supination of the forearm. It can be argued that the presence of supernumerary heads of biceps brachii muscle increase its kinematics. Therefore, from anatomical standpoint of view it can be presumed that the presence of a third head may increase the power of flexion and supination of the forearm (Kumar et al.). In addition to allowing the elbow flexion irrespective of the shoulder joint position, the third head of biceps brachii may enhance the strength of elbow flexion (Swieter \& Carmichael, 1980).

\section{ACKNOWLEDGEMENT}

The authors wish to thank Dr. Erandi Attanayake, Faculty of Medicine, University of Ruhuna, Sri Lanka, for helping with the dissections.

ILAYPERUMA, I.; NANAYAKKARA, G. \& PALAHEPITIYA, N. Incidencia de la cabeza humeral del músculo bíceps braquial. Visión anatómica. Int. J. Morphol., 29(1):221-225, 2011.

RESUMEN: El músculo bíceps braquial se conoce como uno de los músculos que muestra las variaciones anatómicas más frecuentes. Su anomalía más común es la presencia de un fascículo accesorio proveniente del húmero, que se denomina cabeza humeral del músculo bíceps braquial. La evidencia muestra una clara tendencia racial en la incidencia de la cabeza humeral del músculo bíceps braquial. El conocimiento acabado de esta variación, en las diferentes poblaciones, es importante para las intervenciones quirúrgicas del brazo, en los síndromes de compresión nerviosa y en los síndromes de dolor inexplicable en la región del brazo o del hombro. El objetivo de este estudio fue determinar la incidencia y las características morfológicas de este músculo en una población adulta de Sri Lanka. Fueron estudiados los miembros superiores en 135 cadáveres, disecados para evaluar la presencia de las cabezas del músculo bíceps braquial accesorio. Fueron registrados el origen e inserción de la cabeza humeral del músculo bíceps braquial, así como su dimensión cráneo-caudal, anteroposterior y mediolateral. La incidencia de la cabeza humeral del músculo bíceps braquial se encontró en el 3,7\% de los miembros estudiados. En todos los casos, su presencia era unilateral y sólo presente en hombres. La cabeza humeral se originó en la región antero-medial de la diáfisis del húmero, descendió y se fusionó con las otras dos cabezas para formar un tendón común. Los resultados de este estudio resaltan aún más las variaciones raciales en la incidencia de la cabeza humeral del músculo bíceps braquial, entre los habitantes de Sri Lanka. El conocimiento de la presencia de la cabeza humeral del músculo bíceps braquial puede facilitar el diagnóstico preoperatorio, así como los procedimientos quirúrgicos del miembro superior, evitando las lesiones iatrogénicas.

PALABRAS CLAVE: Cabeza humeral del bíceps braquial; Variación anatómica; Sri Lanka.

\section{REFERENCES}

Asvat, R.; Candler, P. \& Sarmiento, E. E. High incidence of the third head of biceps brachii in South African populations. J. Anat., 182:101-4, 1993.

Bergman, R. A.; Thompson, S. A.; Afifi, A. K. \& Saadeh, F.
A. Compendium of human anatomic variation. $1^{\text {st }} \mathrm{Ed}$. Baltimore, Urban and Schwarzenberg, 1988.

Khaledpour, C. Anomalies of the biceps muscle of the arm. Anat. Anz., 158:79-85, 1985. 
Kopuz, C.; Sancack, B. \& Ozbenli, S. On the incidence of the third head of biceps brachii in Turkish neonates and adults. Acta. Anat. Nippon., 74:301-5, 1999.

Kosugi, K.; Shibata, S. \& Yamashita, H. Supernumerary head of biceps brachii and branching pattern of the musculocutaneous nerve in Japanese. Surg. Rad. Anat., 14:175-85, 1992.

Kumar, H.; Das, S. \& Rath, G. An anatomical insight into the third head of biceps brachii muscle. Bratisl. Lek. Listy., 109:76-8, 2008.

Nakatani, T.; Tanaka, S. \& Mizukami, S. Bilateral fourheaded biceps brachii muscles: the median nerve and brachial artery passing through a tunnel formed by a muscle slip from the accessory head. Clin. Anat., 11:20912,1998 .

Nayak, S. R.; Ashwin, K.; Madhan, K. S. J.; Latha, V. P.; Vasudha, S. \& Merin, M. T. Four-headed biceps and triceps brachii muscles with neurovascular variation. Anat. Sci. Intl., 83:107-11, 2008.

Rai, R.; Ranade, A. V.; Prabhu, L. V. \& Prakash, M. M. P. Third head of Biceps brachii: A study in Indian population. Singapore Med. J., 48:929-31, 2007.

Rincon, F.; Rodriquez, I. Z. \& Sanchez A. The anatomic characteristics of the third head of biceps brachii muscle in Colombian population. Rev. Chil. Anat., 20:197-200, 2002.

Roberts, W. H. Anomalous course of the median nerve medial to the trochlea and anterior to the medial epicondyle of the humans. Anat. Anz., 174:309-11, 1992.

Santo Neto, H.; Camilli, J. A.; Andrade, J. C.; Meciano, F. J. \& Marques, M. J. On the incidence of the biceps brachii third head in Brazilian white and blacks. Anat. Anz., 180:69-71, 1998.

Sargon, M. F.; Tuncali, D. \& Celik, H. H. An unusual origin for the accessory head of biceps brachii muscle. Clin. Anat., 9:160-2, 1996.

Swieter, M. G. \& Carmichael, S. W. Bilateral three-headed biceps brachii muscles. Anat. Anz., 148:346-9, 1980.

Testut, L. \& Latarjet, A. Compendio de anatomia descriptive. 22nd Ed. Buenos Aires, Salvat, 1981.
Torre, F. R. L.; Cegarra, J. N. \& Berruezo, J. P. Biceps brachii muscle attached to the extensor carpii radialis brevis muscle: an unreported anatomical variation in humans. Anat. Anz., 176:319-21, 1994.

Tountas, C. P. \& Bergman, R. A. Anatomic variations of the upper extremity. New York, Churchill Livingstone, 1993.

Warner, J. P.; Palleta, G. A. \& Warren, R. F. Accessory Head of the Biceps brachii, Case report demonstrating clinical relevance. Clin. Ortho. Res., 280:179-81, 1992.

Williams, P. L.; Bannister, L. H.; Berry, M. M.; Collins, P.; Dyson, M. \& Dussek, J. E. Gray's Anatomy: The anatomical basis of medicine and surgery. $38^{\text {th }} \mathrm{Ed}$. New York, Churchill Livingstone, 2000.

Correspondence to:

Dr. Isurani llayperuma, Ph.D.

Department of Anatomy

Faculty of Medicine

University of Ruhuna

P.O.Box 70, Galle

Sri Lanka

Telephone: 0094-91-2234801

Fax: 0094-91-2222314

Email: iisurani@yahoo.com

Received: 11-07-2010

Accepted: 19-11-2010 